\title{
HUBUNGAN TINGKAT PENGETAHUAN DAN SIKAP REMAJA PUTRI TENTANG SEKSUAL PRA NIKAH DI SMA NEGERI "Y" KOTA BATAM TAHUN 2016
}

\author{
Relationship Of Knowledge And Attitude About Youth In Sexual Pra Marital \\ SMAN "Y" Batam City 2016
}

\author{
Erika Fariningsih I' \\ *I Program Studi Kebidanan, \\ STIKes Awal Bros Batam, \\ Batam, Kepulauan Riau, \\ Indonesia.
}

*email: rika.fn13@gmail.com

\begin{abstract}
Abstrak
Perilaku seks pranikah pada remaja adalah segala tingkah laku remaja yang didorong oleh hasrat baik dengan lawan jenis maupun sesama jenis yang dilakukan sebelum adanya hubungan resmi sebagai suami istri. Objek seksualnya bisa berupa orang lain, orang dalam khayalan, atau diri sendiri. Macam seks pra nikah antara lain: kissing, necking, petting, intercourse. Sekitar 54\% remaja wanita lajang telah kehilangan keperawanannya. Tujuan dari penelitian ini yaitu untuk mengetahui Hubungan Pengetahuan Dan Sikap Remaja Putri Dengan Perilaku Seksual Pra Nikah Di SMA Negeri "Y" Kota Batam Tahun 2016. Penelitian ini merupakan penelitian kuantitatif dengan desain penelitian analitik yang menggunakan pendekatan Cross Sectional, sampel yang diambil menggunakan Metode Probability Sampling dan teknik Simple Sampling dan jumlah sample 218 responden. Hasil penelitian sebagian besar responden yang memiliki pengetahun baik tentang perilaku seksual pra nikah yaitu sebanyak 2 II responden (96.8\%) dan sikap positif tentang perilaku seksual pra nikah sebanyak 132 responden (60.6\%). Dari hasil uji Chi-Square penelitian pengetahuan ini $p$ value $0,001>0,05$ dan sikap $p$ value $0,002>0,05$. Kesimpulan dari hasil penelitian ini Ada Hubungan Pengetahuan Dan Sikap Remaja Putri Tentang Perilaku Seksual Pra Nikah Di SMA Negeri "Y" Kota Batam.
\end{abstract}

\author{
Kata Kunci: \\ Pengetahuan, \\ Sikap, \\ Seksual Pra Nikah \\ Keywords: \\ Knowledge, \\ Attitudes, \\ Sexual Pre-Marital
}

\begin{abstract}
Premarital sexual behavior in adolescents is all behavior that is driven by the desire teenager well with the opposite sex or same-sex committed before their official relationship as husband and wife. Sexual objects could be someone else, people in the delusion, or self. Kinds of premarital sex among other things: kissing, necking, petting, intercourse. About $54 \%$ teenage single woman had lost her virginity. The purpose of this study is to determine the relationship Knowledge and Attitudes of Young Women With Pre-Marital Sexual Behavior In SMAN "Y" Batam 2016. In research use quantitative research with analytical design using cross sectional approach, the samples of research use Probability Sampling Methods and techniques Simple Sampling with 218 respondents. The results of the research is most of the respondents who have a good knowledge about sexual behavior before marriage as many as 211 respondents (96.8\%) and a positive attitude about premarital sexual behavior of 132 respondents (60.6\%). From the results of Chi-Square test knowledge study is $p$ value $0,001>0,05$ and attitudes $p$ value $0.002>0.05$. The conclusion of this research is There are Relationship Knowledge and Attitudes About Sexual Behaviour of Young Women Pre Marital In SMAN "Y” Batam.
\end{abstract}

(C) year The Authors. Published by Institute for Research and Community Services Universitas Muhammadiyah Palangkaraya. This is Open Access article under the CC-BY-SA License (http://creativecommons.org/licenses/by-sa/4.0/). DOI: https://doi.org//0.33084/jsm.vxix.xxx.

\section{PENDAHULUAN}

Remaja atau Adolescence adalah tumbuh kearah kematangan fisik, sosial maupun psikologis, periode perkembangan selama individu mengalami perubahan dari masa kanak-kanak menuju dewasa (Sarwono, 2010). Remaja adalah usia dimana individu berinteraksi dengan masyarakat dewasa, usia dimana anak tidak lagi merasa dibawah tingkatan orang-orang lebih tua melaikan berada pada tingkat yang sama (Hurlock, 2012).

Ada beberapa faktor yang mendorong anak remaja usia sekolah SMP dan SMA melakukan hubungan seks di luar nikah. Faktor-faktor tersebut di antaranya pengaruh liberalisme atau pergaulan hidup bebas, faktor 
lingkungan dan keluarga yang mendukung ke arah perilaku tersebut serta pengaruh perkembangan media massa. Arus informasi melalui media masa baik berupa majalah, surat kabar, tabloid maupun media elektronik seperti radio, televisi, dan komputer, mempercepat terjadinya perubahan. Meskipun arus informasi ini menunjang berbagai sektor pembangunan, namun arus informasi ini juga melemahkan sistem sosial ekonomi yang menunjang masyarakat indonesia. Remaja merupakan salah satu kelompok penduduk yang mudah terpengaruh oleh arus informasi baik yang negatif maupun yang positif. Perbaikan status wanita, yang terjadi lebih cepat sebagai akibat dari transisi demografi dan program keluarga berencana telah mengakibatkan meningkatnya umur kawin pertama dan bertambah besarnya proporsi remaja yang belum kawin (BKKBN, 2010).

Dari World Health Organization (WHO) menunjukkan bahwa di seluruh dunia, lebih dari I,8 miliar penduduknya berusia 10-24 tahun dan 90\% diantaranya tinggal di negara berkembang (PBB, 20I3). Hasil sensus penduduk tahun 2010 menunjukan bahwa kelompok usia remaja 10-24 tahun merupakan populasi terbesar. Jumlah populasi remaja Indonesia mencapai 63,4 juta $(26,78 \%)$ dari 237,6 juta yang terdiri dari $50,7 \%$ laki-laki dan $49,3 \%$ perempuan.

Beberapa wilayah di Indonesia seperti surabaya sekitar $54 \%$ remaja wanita lajang telah kehilangan keperawanannya kemudian di bandung $47 \%$ dan medan sebanyak 52\%. Angka-angka tersebut merupakan hasil survei yang dilakukan oleh BKKBN selama kurun waktu tahun 20I0. Besarnya angka seks pranikah yang terjadi di kalangan remaja di Indonesia menjadi sebuah ancaman yang cukup serius dan dapat menyebabkan kehancuran moral bangsa (BKKBN, 2008).

Menurut survei demografi dan kesehatan Indonesia (SDKI) 2012 dibandingkan dengan SDKI 2002 dan 2007, terjadi peningkatan hubungan seks pranikah remaja. Survei yang menggunakan data sekunder SDKI 2012 tentang kesehatan reproduksi remaja ini dilakukan terhadap remaja perempuan dan laki-laki yang belum menikah. Hasilnya, 8,3 persen remaja laki-laki dan I persen remaja perempuan melakukan hubungan seks pranikah. Hubungan seksual terbanyak dilakukan pada remaja usia 20-24 tahun sebesar 9,9 persen, dan 2,7 persen pada usia, 15-19 tahun.

Faktor yang diperkirakan menjadi penyebab utama yakni perilaku pacaran remaja di samping semakin banyaknya remaja yang berpacaran. Remaja di bawah 13 tahun sekarang sudah banyak yang berpacaran, sehingga melakukan hubungan seks sebelum menikah tambah banyak. Akibat yang paling besar, kehamilan sebelum menikah. Pasalnya, gempuran informasi dari sikap remaja yang suka mengakses video yang fulgar melalui media massa dan internet. Orang tua juga mesti memberikan pengawasan terhadap lingkungan bermain dan teman bergaul remaja. Jika mampu, berikan fasilitas dan kegiatan yang memungkinkan remaja aktif dan produktif.

Berdasarkan hasil survei pengetahuan remaja tahun 2012 oleh komisi penanggulangan AIDS (KPAP) Kepulauan Riau tahun 2012 tentang kesehatan reproduksi, seksualitas dan HIVIAIDS dan menunjukkan bahwa hanya $22 \%$ yang membuktikan pengetahuan remaja di Provinsi Kepulauan Riau masih sangat rendah sehingga mengakibatkan banyaknya perilaku berisiko hingga pada hubungan seks yang tidak aman, kehamilan yang tidak diinginkan.

Dari keseluruhan remaja 10-24 tahun yang berstatus belum menikah adalah 86,7 persen. Pada kelompok remaja dengan status belum kawin, pada laki-laki 3,0 persen dan perempuan I,I persen, menjawab pernah berhubungan seksual. Lebih lanjut dapat diketahui pula bahwa umur pertama berhubungan seksual sudah terjadi pada usia yang sangat muda, yaitu 8 tahun. Terdapat 0,5 persen perempuan telah melakukan hubungan seksual pertama kali pada usia 8 tahun, dan 0,I persen pada laki-laki. dikaji bahwa penggunaan kontrasepsi sangat terbatas pada saat berhubungan seksual, 23,4 persen pada laki-laki dan hanya 5,3 persen 
pada perempuan. Sudah terlihatnya remaja usia 10-24 tahun yang berstatus belum menikah telah berhubungan seksual, penyuluhan kesehatan reproduksi sangat diperlukan. Dari analisis ini, kelompok remaja yang pernah mendapat penyuluhan kesehatan reproduksi baru 25, I persen. Bervariasi antar provinsi dari yang terendah di Provinsi Sulawesi Barat (9,8\%) dan terbaik Provinsi DI Yogyakarta (57, I\%). Berdasarkan kelompok umur, terlihat kelompok remaja usia 10-14 tahun yang terendah mendapatkan penyuluhan kesehatan reproduksi (13,7\%) dibanding kelompok umur diatasnya Berdasarkan tempat tinggal remaja yang tinggal di perkotaan cenderung mendapat penyuluhan kesehatan reproduksi lebih tinggi dibanding perdesaan (32,2\% dan 17,3\%) (RESIDENSI, 20I0).

Hasil penelitian yang dilakukan pada 1038 remaja yang berusia 13-17 tahun terhadap adanya hubungan seksual menunjukkan bahwa $16 \%$ remaja menyatakan setuju dengan hubungan seksual, $43 \%$ menyatakan tidak setuju terhadap hubungan seksual dan $41 \%$ menyatakan bolehboleh saja melakukan hubungan seksual (Planned Parenthood Federation of America Inc, 2008).

Angka tindak aborsi berdasarkan hasil survey tercatat 2.000.000 kasus aborsi per tahun. Hal ini menandakan 37 aborsi per 1000 wanita usia 15-19 tahun atau 43 aborsi per 100 kelahiran hidup atau 30 persen dari kehamilan (Paulinus Soge, 2008). Dampak dari tidak aborsi sendiri berakibat: pendarahan, infeksi, kemandulan, bahkan kematian (Aliyah, 20I2).

Indonesia sendiri dari penelitian Sahabat Remaja tahun 2004 tentang perilaku seksual di empat kota menunjukkan bahwa 3,6\% remaja kota Medan, 8,5\% remaja kota Yogyakarta, 3,4\% remaja kota Surabaya dan $31,1 \%$ remaja kota Kupang telah aktif melakukan hubungan seks yang aktif. Penelitian yang pernah dilakukan oleh pusat penelitian kependudukan UGM menemukan di Yogyakarta sekitar 15,5\% dan di pedesaan $0,5 \%$ remaja telah melakukan hubungan seks sebelum menikah (Tito, 20I0).
Dari hasil gambaran dan wawancara bersama guru bimbingan konseling (BK) di SMA Negeri "Y" Kota Batam yang dilakukan penulis didapatkan bahwa ada beberapa siswi yang melakukan hubungan seksual sebelum menikah tetapi siswi tersebut tidak sampai dikeluarkan dari sekolah, untuk angka kejadian tersebut dari pihak sekolah tidak membuat catatan secara tertulis. Dari hasil wawancara penulis, penulis tertarik untuk mengambil sempel di SMA Negri "Y”' Kota Batam. Siswi yang menduduki kelas I dan kelas II IPA dan IPS berjumlah 478 orang, dari jumlah data siswi sebanyak 478 peneliti menggunakan rumus Slovin untuk mengambil sampel dari total populasi yang ada yaitu didapatkan sebanyak 218 orang sebagai sampel dari populasi yang ada untuk bahan penelitian.

Berdasarkan latar belakang diatas penulis tertarik untuk melakukan penetilian mengenai Hubungan Pengetahuan dan Sikap Remaja Putri Tentang Perilaku Seksual Pra Nikah di SMA Negeri "Y” Kota Batam Tahun 2016.

\section{METODOLOGI}

Berdasarkan jenis data, penelitian ini merupakan penelitian yang menggunakan metode kuantitatif, yaitu data yang dinyatakan dalam bentuk angka (Notoatmodjo, 20I2)

Penelitian ini menggunakan metode analitik yang bersifat korelasi dengan pendekatan cross sectional dimana data yang menyangkut variabel bebas dan variabel terikat dikumpulkan dalam waktu yang bersamaan (Notoatmodjo, 20I2).

Populasi dalam penelitian ini adalah semua siswi kelas I dan II IPA dan IPS di SMA Negeri "Y” Kota Batam tahun 2016, yang berjumlah 478 orang. Menggunakan teknik Sempel Sampling di dapat hasil sebanyak 218 orang yang akan di jadikan sampel.

\section{HASIL DAN PEMBAHASAN}

Hasil Analisa Univariat 
a. Distribusi Variabel Dependen Perilaku Seksual Pra Nikah Di SMA Negeri “Y” Kota Batam Tahun 2016

Tabel I.

Distribusi Variabel Dependen Perilaku Seksual Pra Nikah Di SMA Negeri "Y” Kota Batam Tahun 2016

\begin{tabular}{lcc}
\hline \multicolumn{1}{c}{ Perilaku } & $\begin{array}{c}\text { Frekuensi } \\
\text { (f) }\end{array}$ & Persentasi (\%) \\
\hline Pacaran & 76 & 34.9 \\
Duduk berdua & 144 & 66.1 \\
Berpegangan tangan & 87 & 39.9 \\
Mengelus rambut pasangan & 83 & 38.1 \\
Memeluk & 69 & 31.7 \\
Mencium kening & 35 & 16.1 \\
Mencium pipi & 40 & 18.3 \\
Tempat gelap & 21 & 9.6 \\
Mencium bibir & 24 & 11.0 \\
Mencium leher & 8 & 3.7 \\
Meraba bagian tubuh & 10 & 4.6 \\
Memegang alat kelamin & 7 & 3.2 \\
Menggesekkan bagian tubuh & 7 & 3.2 \\
yang sensitif & & \\
Menempelkan kedua alat & 7 & 3.2 \\
kelamin & & 3.7 \\
Hubungan seksual & & \\
\hline Sumber: Data Primer, 20/6 & &
\end{tabular}

b. Distribusi Frekuensi Pengetahuan Remaja Putri Tentang Perilaku Seksual Pra Nikah Di SMA Negeri "Y" Kota Batam Tahun 2016

Tabel II.

Distribusi Frekuensi Pengetahuan Remaja Putri Tentang Perilaku Seksual Pra Nikah Di SMA Negeri "Y" Kota Batam

Tahun 2016

\begin{tabular}{ccc}
\hline Pengetahuan & $\begin{array}{c}\text { Frekuensi } \\
\text { (f) }\end{array}$ & Persentasi (\%) \\
\hline Kurang Baik & 7 & 3.2 \\
Baik & 211 & 96.8 \\
\hline JUMLAH & $\mathbf{2 1 8}$ & $\mathbf{1 0 0}$ \\
\hline Sumber : Data Primer, 2016 & &
\end{tabular}

c. Distribusi Frekuensi Sikap Remaja Putri Tentang Perilaku Seksual Pra Nikah Di SMA Negeri "Y" Kota Batam Tahun 2016.
Tabel III.

Distribusi Frekuensi Sikap Remaja Putri Tentang Perilaku Seksual Pra Nikah Di SMA Negeri “Y” Kota Batam Tahun 2016

\begin{tabular}{ccc}
\hline Sikap & $\begin{array}{c}\text { Frekuensi } \\
\text { (f) }\end{array}$ & $\begin{array}{c}\text { Persentase } \\
\text { (\%) }\end{array}$ \\
\hline Negatif & 86 & 39.4 \\
Positif & 132 & 60.6 \\
\hline JUMLAH & 100 & 100
\end{tabular}

\section{Hasil Analisa Bivariat}

a. Hubungan Tingkat Pengetahuan Remaja Putri tentang Perilaku Seksual Pra Nikah di SMA Negeri "Y" Kota Batam Tahun 2016.

\section{Tabel IV.}

Hubungan Tingkat Pengetahuan Remaja Putri Tentang Perilaku Seksual Pra Nikah Di SMA Negeri "Y” Kota Batam Tahun 2016 


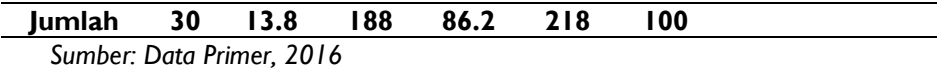

\section{PEMBAHASAN}

\section{a. Tingkat Pengetahuan Remaja Putri SMA} Negeri "Y" Kota Batam Tentang Perilaku Seksual Pra Nikah

Berdasarkan hasil penelitian menunjukkan bahwa dari 218 responden remaja putri SMA Negeri " $Y$ " Kota Batam, lebih banyak memiliki pengetahuan baik sebanyak 211 responden (96.8\%), dibandingkan dengan responden memiliki pengetahuan kurang baik sebanyak 7 responden (3.2\%).

Hal ini disebabkan oleh pengetahuan remaja putri SMA Negeri "Y" Kota Batam tentang perilaku seksual pra nikah didapatkan melalui beberapa cara seperti, banyaknya informasi yang diperoleh remaja putri misalnya dari televisi, internet, koran, majalah, leaflet, buku, seminar ataupun spanduk yang tersedia, serta jenjang pendidikan yang telah dilewati oleh remaja siswi tersebut. Selain itu lebih banyak remaja putri berada dilingkungan yang mendukung seperti dukungan keluarga atau lingkungan sekitar terhadap perilaku yang tidak menyimpang.

Berdasarkan hasil penelitian diatas menunjukkan bahwa tingkat pengetahuan remaja putri yang baik mampu memberikan prilaku seksual pranikah pada remaja tidak beresiko. Hal ini sesuai dengan teori yang dikemukakan oleh Notoatmodjo (2012) semakin tinggi pendidikan seseorang, maka semakin baik pula pengetahuan yang akan didapatkan.

Menurut Notoatmodjo (20I2), faktor yang mempengaruhi pengetahuan yaitu pendidikan, ekonomi, paparan media massa, hubungan sosial, pengalaman dan umur. Tingkat pendidikan seseorang akan berpengaruh terhadap pemberian respon terhadap suatu yang datang dari luar. Orang yang berpendidikan tinggi akan memberi respon yang lebih rasional terhadap informasi yang datang dan akan berfikir sejauh mana keuntungan yang mungkin akan mereka peroleh dari informasi tersebut.
Hasil ini mendukung dari penelitian yang dilakukan oleh Nur Gilang Fitriana (2010), bahwa lebih banyak responden yang memiliki pengetahuan baik sebanyak 14 orang $(46,7 \%), 12$ orang $(40 \%)$ responden dengan berpengetahuan cukup tentang perilaku seksual pra nikah.

b. Sikap Remaja Putri SMA Negeri "Y" Kota Batam Tentang Perilaku Seksual Pra Nikah

Berdasarkan hasil penelitian menunjukkan dari 218 responden remaja putri di SMA Negeri "Y" Kota Batam, lebih banyak sikap positif tentang perilaku seksual pra nikah sebanyak 132 responden $(60,6 \%)$, dibandingkan dengan sikap negatif tentang perilaku seksual pra nikah sebanyak 86 responden (39.4\%). Hal ini disebabkan oleh sikap remaja putri SMA Negeri " $Y$ " Kota Batam tentang perilaku seksual pra nikah menunjukkan bahwa lebih banyak remaja putri yang bersikap positif dikarenakan pengalaman orang lain yang dijadikan sebagai pembelajaran dalam menyikapi suatu hal. Disamping itu faktor lain yang mempengaruhi sikap remaja putri yaitu Melalui paparan media seperti, banyaknya informasi yang diperoleh remaja putri misalnya dari televisi, internet, koran, majalah, leaflet, buku, seminar ataupun spanduk yang tersedia, serta jenjang pendidikan yang telah dilewati oleh remaja putri tersebut. Selain dari media massa kebudayaan juga mempengaruhi sikap remaja putri.

Berdasarkan hasil penelitian diatas menunjukkan bahwa sikap remaja putri yang baik mampu menjadikan perilaku seksual pranikah tidak beresiko pada remaja tersebut. Hal ini sesuai dengan teori yang dikemukakan oleh Notoatmodjo (20I2) semakin tinggi pendidikan seseorang, maka semakin baik pula pengetahuan yang akan didapatkan.

Menurut Azwar (2007), faktor-faktor yang mempengaruhi sikap adalah pengalaman peribadi, kebudayaan, orang lain yang dianggap penting, dan media massa. Dari hasil penelitian yang telah 
dilakukan, hal ini sesuai dengan pernyataan Widyatun (2008) bahwa yang mendorong seseorang untuk melakukan suatu tindakan karena adanya kemauan.

Menurut Wawan dan Dewi (2010) sikap seseorang sangat dipengaruhi oleh pengalaman pribadi, Baik itu pengalaman baik itu pengalaman dirinya sendiri maupun pengalaman dari orang lain yang dapat menunjang sikap seseorang, kebudayaan, orang lain yang dianggap penting, media massa, institusi atau lembaga pendidikan dan lembaga agama, serta faktor emosi dalam diri individu. Sikap memiliki tingkatan yaitu menerima, merespon, menghargai, dan bertanggung jawab.

Hasil ini mendukung dari penelitian yang dilakukan oleh Nur Gilang Fitriana (2010) dan Kadek Putri Juliani (20/3), bahwa sebagian besar responden memiliki sikap positif terhadap perilaku seksual pra nikah. Hasil penelitian Nur Gilang Fitriana (20I0) responden dengan sikap tidak mendukung jika melakukan perilaku seksual sebanyak 18 orang dengan persentase $(60 \%)$ dan peneliti Kadek Putri Juliani (20I3) responden paling banyak memiliki sikap positif (kecenderungan menghindari perilaku seksual pranikah) berjumlah 57 orang dengan persentase $(83,8 \%)$.

\section{c. Hubungan Pengetahuan Remaja Putri} Tentang Perilaku Seksual Pra Nikah Di SMA

\section{Negeri "Y" Kota Batam}

Berdasarakan hasil penelitian menunjukkan bahwa dari 218 responden remaja putri SMA Negeri "Y" Kota Batam, sebagian besar memiliki pengetahuan baik dengan perilaku seksual pra nikah yang tidak beresiko 186 responden (88.2\%), dengan hasil perhitungan Chi-Square didapatkan nilai $p$-value sebesar 0,00I sehingga hasil p-value 0,001 <0,05, maka dapat disimpulkan bahwa ada hubungan yang signifikan antara pengetahuan remaja putri dengan perilaku seksual pra nikah di SMA Negeri "Y" Kota Batam.
Umumnya remaja putri telah memperoleh pengetahuan tentang perilaku seksual pra nikah dengan berbagai cara misalnya mencari informasi melalui media massa atau elektronik. Sedangkan untuk sikap tentang perilaku seksual pra nikah sebagian besar remaja putri telah melakukan beberapa cara untuk menghindari perilaku seksual pra nikah, baik secara by your self atau dengan pengalaman yang didapat dari orang-orang sekitar yang mempunyai pengalaman akan perilaku seksual pra nikah. Dimana pengalaman seseorang dapat berpengaruh terhadap sikap seseorang. Tidak hanya tingginya pendidikan yang telah ditempuh, tingkat pengetahuan yang tinggi serta lingkungan hidup yang memadai dapat mendukung respon terhadap suatu objek. Tetapi terdapat faktor pendukung lainnya yang dapat membantu penilaian sikap seseorang terhadap suatu objek. Selain itu, adapun faktor lain yang mempengaruhi sikap tentang perilaku seksual pra nikah oleh remaja putri pengalaman pribadi, kebudayaan, orang lain yang dianggap penting, media massa, institusi atau lembaga pendidikan dan lembaga agama, serta faktor emosi dalam diri

$\mathrm{Hal}$ ini menunjukkan bahwa sebagian besar responden remaja putri telah menghindari perilaku seksual pra nikah melalui beberapa cara dengan memperbanyak pengetahuan tentang seksual pra nikah, menghindari pergaulan bebas, lebih memperbanyak kegiatan yang positif tentang keagamanan. Hal ini sejalan dengan teori yang dikemukakan oleh Notoatmodjo (2012) dapat dikatakan bila semakin banyak pengalaman seseorang maka semakin baik pula pengetahuan seseorang tersebut.

Penelitian ini didukung oleh pernyataan Notoatmodjo (2012) yaitu adapun faktor-faktor yang mempengaruhi pengetahuan salah satunya adalah pendidikan, tidak dapat dipungkiri bahwa semakin tingginya pendidikan seseorang maka semakin banyak juga informasi yang seseorang 
peroleh sehingga pengetahuan seseorang semakin bertambah akan suatu objek tertentu. Sebaliknya jika tingkat pendidikan seseorang rendah, maka hal tersebut akan mengurangi atau menghambat perkembangan sikap seseorang dalam menerima suatu informasi terhadap sebuah objek dan nilai-nilai yang baru diperkenalkan. Sehingga menurut Wawan dan Dewi (2010) mengenai Sikap, yaitu: pengalaman pribadi, kebudayaan, orang lain yang dianggap penting, media massa, institusi atau lembaga pendidikan dan lembaga agama, serta faktor emosi dalam diri individu.

Dari hasil penelitian yang telah dilakukan didapatkan bahwa pengetahuan akan perilaku seksual pra nikah dominan baik. Semakin banyak pengetahuan akan seksual pra nikah yang dimiliki semakin kecil peluang terjadinya penyimpangan akan perilaku seksual pra nikah. Penelitian ini sejalan dengan beberapa peneliatian sebelumnya oleh Nur Gilang Fitriana (2010) bahwa pengetahuan tentang perilaku seksual pra nikah lebih banyak responden yang memiliki pengetahuan baik. Penelitian ini bertujuan untuk melihat Hubungan Antara Pengetahuan Dengan Perilaku Seksual Pra Nikah di SMA Negeri "Y” Kota Batam Tahun 2016.

Kesimpulan dari hasil penelitian ini berdasarkan beberapa pernyataan yang dikemukakan oleh beberapa sumber buku, maka ditemukan adanya hubungan antara pengetahuan remaja putri tentang perilaku seksual pra nikah di SMA Negeri "Y" Kota Batam.

\section{d. Hubungan Sikap Remaja Putri Tentang Perilaku Seksual Pra Nikah Di SMA Negeri "Y" Kota Batam}

Berdasarkan hasil penelitian menunjukkan bahwa dari 218 responden remaja putri SMA Negeri "Y" Kota Batam, sebagian besar memiliki sikap positif tentang perilaku seksual pra nikah yang tidak beresiko 122 responden (92.4\%), sedangkan sikap negatif tentang perilaku seksual pra nikah yang beresiko sebanyak 20 responden (23,3), dengan hasil perhitungan Chi-Square didapatkan nilai $p$-value sebesar 0,002 sehingga hasil $p$ value $0,002<0,05$, maka maka dapat disimpulkan bahwa ada hubungan yang signifikan antara pengetahuan remaja putri dengan perilaku seksual pra nikah di SMA Negeri "Y" Kota Batam.

Hal ini adanya kemauan remaja putri untuk menghindari perilaku seksual pra nikah dengan cara mengikuti kegiatan yang bersifat positif seperti mengikuti acara keagaman. Berpartisipasi dalam segala kegiatan yang bersifat positif. Disamping itu dukungan atau motivasi dari keluarga yang berperan penting dalam pembentukan sikap dan perilaku remaja tersebut.

Selain itu, lingkungan remaja putri tinggal masih menjunjung tinggi kebudayaan timur sehingga penyimpangan sikap seksual pra nikah sangat minim beresiko. Menurut Azwar (2007), faktor-faktor yang mempengaruhi sikap adalah pengalaman peribadi, kebudayaan, orang lain yang dianggap penting, dan media massa.

Menurut Gerungan (2009) menyatakan bahwa adapun faktor-faktor yang mempengaruhi perilaku seseorang akan suatu objek yaitu: minat, kebutuhan yang searah, suasana hati, pengalaman dan ingatan. Sehingga kurang lebihnya perilaku seseorang akan berhubungan erat dengan pengalaman yang dimiliki maupun pengalaman yang orang lain miliki.

Dari hasil penelitian yang telah dilakukan dipapatkan bahwa sikap positif dominan akan perilaku seksual pra nikah dibandingan dengan perilaku negative seksual pra nikah pada kalangan remaja. Perilaku yang positif mampu mencegah perilaku seksual pra nikah yang terjadi dikalangan siswi SMA Negeri "Y” Kota Batam. Penelitian ini sejalan dengan beberapa peneliatian sebelumnya oleh Nur Gilang Fitriana (2010) dan kadek putri juliani (2013), bahwa sebagian responden memiliki sikap positif terhadap perilaku seksual pra nikah. Penelitian ini bertujuan untuk mengetahui adanya hubungan sikap 
dengan perilaku seksual pra nikah di SMA Negeri "Y" Kota Batam.

Kesimpulan dari hasil penelitian ini berdasarkan beberapa pernyataan yang dikemukakan oleh beberapa sumber buku, maka ditemukan adanya Hubungan Antara Pengetahuan Remaja Putri Tentang Perilaku Seksual Pra Nikah di SMA Negeri "Y” Kota Batam.

\section{KESIMPULAN}

Hasil penelitian menunjukkan bahwa dari 218 remaja putri di SMA Negeri "Y" Kota Batam tahun 2016 sebagaian besar mempunyai pengetahuan yang baik tentang perilaku seksual pra nikah sebanyak 21I responden (96.8\%). Hasil penelitian menunjukkan bahwa dari 218 remaja putri di SMA Negeri "Y" Kota Batam tahun 2016 sebagian besar memiliki sikap positif tentang seksual pra nikah sebanyak 132 responden (60.6\%). Dari hasil penelitian yang telah dilakukan, adanya Hubungan Tingkat Pengetahuan dan Sikap Remaja Putri tentang Perilaku Seksual Pra Nikah di SMA Negeri "Y” Kota Batam Tahun 2016

\section{UCAPAN TERIMA KASIH}

Terimakasih disampaikan kepada Program Studi Kebidanan dan seluruh Civitas STIKes Awal Bros Batam atas dukungannya dalam pelaksanaan kegiatan penelitian ini.

\section{REFERENSI}

I. Aziz, Azimul. 20 10. Metode Penelitian Kebidanan dan Teknik Analisis Data. Jakarta; Salemba Medika.

2. DR. Kartono, Kartini,20I0. Psikologi Wanita Mengenal IGadis Remaja Dan Wanita Dewasa. Bandung; Mandar Maju.

3. Departemen Kesehatan Republik Indonesia. 2010. Laporan Hasil Riset Kesehatan Dasar Indonesia (Riskesdas).

4. Elizabeth, B. Hurlock, 20I2. Psikologi Perkembangan, Jakarta; Erlangga.
5. Nur Gilang Fitriana, Hubungan Pengetahuan dan Sikap Tentang Seks Pranikah Dengan Perilaku Seksual Pada Siswa Smk Xx Semarang.

6. Faruq Muhammad, Hubungan Antara Pengetahuan dan Sikap Remaja Tentang Seks Pranikah Di SMA Batik 2 Surakarta.

7. Notoatmodjo, S. 2012. Metodelogi Penelitian Kesehatan. Jakarta; Rineka Cipta.

8. Wawan, dkk. 20I0. Pengetahuan, Sikap dan Perilaku Manusia. Yogyakarta; Nuha Medika.

9. Ayu, Putri Ariani. 2014. Aplikasi Metodologi Penelitian Kebidanan Dan Kesehatan Reproduksi, Yogyakarta; Nur Medika. 